\title{
Contesting anticipatory regimes in education: exploring alternative educational orientations to the future
}

Sarah Amsler, School of Education, University of Lincoln, samsler@lincoln.ac.uk

Keri Facer, Graduate School of Education, University of Bristol, keri.facer@bristol.ac.uk

\section{PRE-PRINT VERSION}

Published (2017) in Futures: The Journal of Policy, Planning and Futures Studies

http://www.sciencedirect.com/science/article/pii/S001632871630177X

\begin{abstract}
Advanced capitalist societies are characterized by three forms of power and powerlessness: a hegemony of political monoculture; the 'undoing' of democratic forms of political agency and subjects; and the 'political construction of hopelessness' in challenging these structural foreclosures and ideological consensus. In this context, how can learning enable collective survival in the present and enlarge possibilities for yet-unimaginable alternative futures to emerge? This paper explores this question by juxtaposing three models of educational futurity in different neoliberal contexts. The first, dominating state education policy and practice in Anglospheric and specifically British institutions, promotes performative and disciplinary regimes of anticipation. The second, circulating in discourse and in experimental spaces within this hegemonic context, advocates an emergentist, critical and creative relationship to the future. The third, which thrives in the margins and relative exteriorities of the capitalist world system, promotes an ecological, epistemically disobedient and utopian mode of anticipatory consciousness which 'projects emancipation beyond the constraints of the existing discourse' of colonial modernity. We do not attempt to compare these different contexts and models in this paper, but to read each for its difference to illustrate that modes of anticipation in education influence the construction of hopelessness and hope by shaping what is learned about the nature of political possibility and the relationship between learning and the future. We argue that pedagogies which embrace critical modes of anticipation offer alternatives to contemporary regimes of anticipation in education in Britain today.
\end{abstract}

\section{Keywords}

anticipatory consciousness; anticipatory regimes; educational futures; epistemic disobedience; hope and hopelessness; neoliberalism

\section{Recommended Citation:}

Amsler, S. and Facer, K. (2017) 'Contesting anticipatory regimes in education: exploring alternative educational orientations to the future', Futures: The Journal of Policy, Planning and Future Studies, http://www.sciencedirect.com/science/article/pii/S001632871630177X. 


\section{Contesting anticipatory regimes in education: exploring alternative educational orientations to the future}

'The future is open and undecided; and it is, I suggest, of supreme importance that those closely involved in education recognise, and struggle consistently to realise, its potential.' (Brian Simon, Does Education Matter? 1985, p. 30)

\section{Learning, the future, and the political construction of hope/lessness}

Advanced capitalist societies are presently characterized by three major forms of power and powerlessness: a hegemony of political monoculture (i.e., that 'there is no alternative' to the status quo) (Amsler 2015); the 'undoing' of democratic forms of political agency, subjects, institutions and states (Brown 2015); and the 'political construction of hopelessness' in challenging these structural foreclosures and ideological consensus (Dinerstein 2014). One product of this agenda is the contraction of the space of political possibility.

As a consequence, many forms of social agency, which once could shift the values and trajectories of the present, are no longer adequate or effective (Cvetkovich 2012). This is partly because the cognitive and socio-economic conditions of their efficaciousness have been altered; partly because their theoretical underpinnings have been deconstructed by epistemological shifts in our knowledge of agency, transformative political process and social change; and partly because adequate responses to ecological, economic and political crises require radical modes of thinking and acting which people formed and socialized through formal education in the global North - despite being able to identify the problem - are often ill-prepared to imagine or engage in. However, while these conditions may be experienced as a totalizing foreclosure of possibility, these times have also given birth to a diversity of social movements which are conceived and organized specifically to challenge the parameters of possibility itself by learning and organizing hope; 'hope movements' towards other realities that are not-yet on the horizon (Dinerstein and Deneulin 2012).

Because education is so often dedicated to the formation of future persons, the realization of social futures, and the advancing of historical projects, this situation raises fundamental questions for educators. After all, the colonization of the future and the active construction of hopelessness, in particular, disrupts the historic anticipatory logic shaping formal education in modern capitalist societies; namely, the linear theorisation of the relationship between learning-in-the-present and being-in-the-future. This logic has underpinned 'liberal', 'conservative', 'progressive' and 'radical' models of schooling within the twentieth-century Anglo-European 'education debate'. Indeed, the debates of the $20^{\text {th }}$ century were characterised not by the question of whether it is possible to create human beings and social futures through education, but which subjects and societies were desirable and how methodologically to educate them.

So, what should a socially and ecologically progressive educational project look like at the present conjuncture, in which collective futures cannot be adequately comprehended, predicted or controlled; in a context which undermines the very proposition that people can successfully learn in the present? What might be required to inhabit, operate, reproduce and develop a consensually determined social imaginary or system? What constitutes an education in and for the 'good society' in the context of post-democratic societies where 'the institutions and principles aimed at securing democracy, the cultures needed to nourish it, the energies needed to animate it, and the citizens practicing, caring for or desiring it... are 
challenged by neoliberalism's "economization" of political life and of other heretofore noneconomic spheres and activities'? (Brown 2015, p. 17) How can people conceptualize the relationship between education and the future in such a way that learning not only enables collective survival in the present or recognizes 'the centrality of education to larger projects of democracy and community building' (De Lissavoy 2011 in Ball 2013), but facilitates the invention of new capacities which enlarge possibilities for yet-unimaginable alternative futures to emerge?

This paper explores these questions by juxtaposing three models of educational futurity in different neoliberal contexts. The first, which predominantly operates in experimental spaces and thought experiments within this hegemonic context, advocates an emergentist, critical and creative relationship to the future through processes of democratic learning (Dewey 1938; Freire 1970/2000; Osberg 2010; Facer 2016). The second, which dominates compulsory (and increasingly post-compulsory) state educational policy and practice in Anglospheric and specifically British institutions, promotes performative and disciplinary regimes of anticipation in which a speculative 'future sets conditions of possibility for action in the present' (Adams et al. 2009, p. 249). The third model, which thrives in the margins and relative exteriorities of the capitalist world system, promotes an ecological, epistemically disobedient and utopian mode of 'anticipatory consciousness' which 'projects emancipation beyond the constraints of the existing discourse' of colonial modernity (Bronner 2013, p. 124). We do not attempt to compare these different contexts and models, but to read each for its difference in order to illustrate two things: first, that counter-hegemonic forms of education are active forces of possibility; and second, that modes of anticipation in education influence the political construction of hopelessness and hope by shaping what is learned about the nature of social reality, the status of political possibility and the relationship between learning and the future. We argue that students and teachers in the United Kingdom face serious challenges in practicing critical, collective and socially just forms of futurity within policy frameworks that foreclose such possibilities, and that recognizing alternative pedagogies and modes of anticipation offer important resources for learning and 'organizing hope' in this context (Dinerstein 2014).

Before pursuing these lines of inquiry, we offer a brief introduction to the notion of anticipation as a particular mode of futurity, and to the concept of the 'anticipatory regime' as an historically and geopolitically specific articulation of anticipation which is both characteristic and productive of speculative capitalism. This discussion sets the stage for exploring how formal education in Britain is captured within regimes of anticipation which prevent critical, creative and democratic relations with the future, and for introducing alternative modes of futurity which enable us to know and remake the present ad infinitum.

\section{Anticipation as critical pedagogical practice}

Anticipation, as Vincanne Adams et al. point out, takes a variety of historically specific forms. It has also 'long been a component of political practice: decolonization, Marxism and feminism all rely on conjuring the possibility of new futures', and in this way a space of both fear and hope in the present $(2009$, p. 248). In this reading, anticipation is thus understood as an 'affective state', a 'regime of being in time, in which one inhabits time out of place as the future' (ibid., p. 247). As a comportment, it is always located in the ontology of the Not-Yet (that which is not impossible but which is not-yet conscious and has not yet become) (Bloch 1995). As an experience, anticipation is not only an emotion but 'operates in the field of hope... as a directing act of a cognitive kind', guiding our sense-making activities beyond 
what is given as possible in ourselves and in the world towards an indeterminate horizon of possibilities (ibid.). In contexts where a new future is not only hoped for but expected in some form to arrive, such as in the aforementioned theories of liberation or programmes of educational reform, anticipation is also a finitely temporal experience. For at the moment expectations of an imagined future are either disappointed or fulfilled, people enter into a non-anticipatory relationship with them (DeRoo 2013, p. 50).

In a critical paradigm, anticipation (or more specifically the exercising of 'anticipatory consciousness') is also essential to the construction of an active political subjectivity which, in Ernst Bloch's words, relies on knowledge 'which is not merely contemplative, but rather...goes with process, which is actively and partisanly in league with the good which is working its way through, i.e. what is humanly worthy in process' - knowledge which is, in other words, concerned with normative judgements about the future (Bloch 1995, p. 198). As what is 'working its way through' is not fully knowable in the present, however, critical anticipatory practice flows between four acts: a rehabilitative one of understanding past knowledges and possibilities which are latent in the present, a utopian one of imagining other realities that might emerge, a disappointing one of learning the limits of this knowledge and imagination as they interact with existing social forces, and a creative one of actively pursuing the realization of the alternative by transforming the fundamental conditions of its possibility through working on the 'unenclosed process-matter' of self, nature and society (ibid., p. 236; see also Dinerstein 2014). Such practices of anticipation have been particularly articulated in Marxist traditions of critique which ascribe to them a messianic function of holding space open for that which cannot be yet imagined and which is always yet-to-come, for a 'necessarily indeterminate, abstract, desert-like experience that is confided, exposed, given up to its waiting for the other and for the event' (Derrida 2012, p. 112).

With learning at its heart, this mode of critical anticipation has many practical implications for educational projects seeking to advance conditions of autonomy, democracy and social justice in a variety of contexts, and to support different processes of liberation. Richard van Heertum has pointed out, for example, that 'gaining appreciation for art and a more critical view of popular media can aid children in beginning to discern the traces of deeper libidinal desires that contemporary society fails to satisfy', and thus to imagine or create for themselves a different kind of society which might do better (2006, p. 49). Kerry Mallan and Ruth Greenaway have described how an intergenerational community action research community planning project in Australia enabled 'young people to recognise the interaction between their own understandings of their world as it is now and the vision of what it might become', within the constraints of a school environment, as it valued the utopian potential of their 'daydreams' and placed them into dialogue with communities (2011, p. 385). Drawing on a cognate set of complexity-theory-informed conversations around how to "take care of the future' in the 'absence of a teleological theory of action', Deborah Osberg has argued that the relationship between learning and becoming must now be one of invention and experimentation rather than control; that it involves 'using the lessons of the past to invent something radically new; something which might accompany us into the future (and also which might not)' (2010, pp. 168-169). Facer (2016) similarly suggests that the unique role of a socially and ecologically relevant education today is thus not to resolve but to put into play relationships between past and present, present and future, and she imagines education as an 'ecotone', a boundary state or estuary between two conditions, such as river/sea or woodland/river, in which temporal dynamics are put up for grabs and new possibilities are able to emerge; a space where teloi themselves become objects of play. 
Ultimately, if (as Ernst Bloch and other critical theorists of anticipation suggest) the individual and collective capacity for active-creative engagement with the future is something that must be learned, then one important function of democratic education is to facilitate this learning. There are many ways to conceptualise such a practice. Early in the twentieth century, the US philosopher John Dewey (1938) argued that the impossibility of speculating the future, due to its emergent properties, made mastery of past and present knowledge a pointless educational objective; he proposed instead the development of capacities to become 'acquainted with a changing world'. In a now-classic formulation, the Brazilian educator Paulo Freire advocated the institutionalization of 'problem-posing' education, in which 'people develop their power to perceive critically the way they exist in the world with which and in which they find themselves; they come to see the world not as a static reality, but as a reality in process, in transformation' (1970/2000, p. 83). He distinguished this anticipatory mode, which 'affirms men and women as beings in the process of becoming - as unfinished, uncompleted beings in and with a likewise unfinished reality', from the authoritarian form of 'banking education' which, in seeking to fill human receptacles (students) with abstract knowledge to be applied in fixed futures, 'emphasizes performance and becomes reactionary'. Problem-posing education, he argued, is on the contrary a practice of 'revolutionary futurity' (ibid., p. 84).

More recently, Osberg has articulated contemporary forms of educational democracy and 'edu-political theory' which care for the proliferation of and experimentation with complex processes of emergence, organized to facilitate productive 'exposure to what is different, strange and other, such that new ways of doing things than are currently found in the world can actually be brought into being' and which encourage the 'idea of an experiment with the possibility of the impossible (i.e., an experiment with that which cannot be conceived of as a possibility)' (2010, p. 169). Jan Masschelein and Maarten Simons (2012) offer a slightly different version of this, defining education, after Hannah Arendt (1968a, 1968b, 1968c), as a site through which 'free time' (and liberated being) can actually be made. Recovering the etymological essences of the Greek word $\sigma \chi 0 \lambda \eta$ (scholè), which include 'free time', 'rest' and 'delay' as well as 'study', 'discussion', 'lecture', 'school' and 'school building', they argue that education can in fact provide a space/time in which to be liberated from existing rules of space and time; a

'time where words are not part (no longer, not yet) of a shared language, where things are not (no longer, not yet) a property and to be used according to familiar guidelines, where acts and movements are not (no longer, not yet) habits of a culture, where thinking is not (no longer, not yet) a system of thought' (2012, p. 103).

In a different context, that of teaching global citizenship and international development, Vanessa Andreotti draws on postcolonial theory which 'highlights complexity, uncertainty, provisionality and complicity in strategies of working against the grain of (neo)colonial and imperial processes' (2011, p. 61) to construct curricular and pedagogical programmes that reopen critical engagements with past, present and future. One called 'Through Other Eyes', for example, was designed to

'enable students to move from the desire for absolute certainties, fixed identities/communities, and predictable and consensual futures towards being comfortable with contingent and provisional certainties, complex and hybrid identities/communities and open co-created futures in the context of global education' (2014). 
Despite their existence and circulation, however, these perspectives are marginalized or censured within official discourses of educational policy in the British and other marketdominated systems of compulsory education. A full discussion of the twentieth and twentyfirst century neoliberalization of public education is beyond the scope of this paper; we begin from the position that 'education policy, education reform are no longer simply a battleground of ideas [but] a financial sector, increasingly infused by and driven by the logic of profit' (Ball 2012, see also Ball 2013; Robertson 2007; Ross and Gibson 2007; Torres 2008; Au and Ferrare 2015), and from the proposition that this system systematically diminishes opportunities for creative emergence and spaces of political possibility in order to reproduce itself at the level of society. Much has already been written about the consequences of this capture of the future for critical knowledge (Apple 2014), pedagogy and curriculum (Paraskeva 2016; Wilkins 2012), educational subjectivity (Atasay 2014; Ball 2015a), social justice (Grimaldi 2012), human flourishing (Henderson and Hursh 2014), ecological survival and sustainability (Hursh et al. 2015), and democratic life (Fielding 2012; Stevenson 2015). The remainder of this paper therefore focuses on the implications of neoliberal education for critical practices of anticipation in education, and specifically the role of 'anticipatory regimes' in closing spaces for such critical, creative and socially just modes of futurity.

\section{The rise of the 'anticipatory regime'}

The notion of the 'anticipatory regime' was introduced by Vincanne Adams, Michelle Murphy and Adele Clarke (2009) to describe a particular (modern) way of feeling, 'thinking and living toward the future' which is governed explicitly by the 'injunction to characterize and inhabit degrees and kinds of uncertainty - adjusting ourselves to routinized likelihoods, hedged bets and probable outcomes'. Their 'exemplary sites of anticipatory practice' include the use of predictions about death to make decisions about health care in the present; prenatal foetal care based on anticipated conditions or behaviours; the production of subjectivities, such as certain forms of 'girlhood' that promise higher economic returns, lower future birth rates and sexually transmitted diseases; the framing of certain spaces and places as untimely and in need of 'anticipatory investment'; the reconfiguration of food chains on the basis of speculations about epidemic, illness and preventative biomedicalization; biosecurity and biodefense; and the preventative eradication of risky behaviours and pathogens (Adams et al. 2009, pp. 250-253). In this mode of anticipation, they argue, we not only imagine the future but discipline our present being and becoming in order to minimize the risks of a future which is 'felt as inevitable in the present'. Possibilistic modes of political action which combine 'big data' and algorithmic reasoning with intuition and imagination are used to identify latent and emergent possibilities in the present in order to identify potential future risks 'whether or not such crises are yet born out in the public sphere' (ibid., p. 252).

While affective and cognitive anticipatory regimes are not reducible to capitalist regimes, both 'work through expansion, in which new territories for speculation must be continually found to keep the anticipatory logic going' (ibid., p. 250). Furthermore, 'as much as speculative finance has become both a dominant mode of capital accumulation, spawning its own material and discursive effects of disaster prediction, anticipation has become a common, lived affect-state of daily life, shaping regimes of self, health and spirituality' (ibid., p. 247). Educators do not only live under such regimes, but actively produce them through skills which are developed through the everyday practice of relating to the future in this context. Successful anticipating subjects in anticipatory regimes, it is argued, accept the injunction that it is necessary and good to await the 'predicted inevitable'; make complex decisions 'in the face of ongoing contingency and ambiguity' through abduction between 
futures, pasts and presents; are constantly optimizing their possibilities of the best future in this flux; master a kind of speculative preparation which treats 'the event and the trauma as if it were already here'; and understand possibility as the 'ratcheting up' of hope that new possibilities, like new markets, are always appearing in zones of risky emergence (ibid., pp. 254-259).

\section{Repressive anticipation and anticipatory repression in British compulsory education}

Thinking and acting towards the future on the basis of quantified and categorized descriptions of the present in this way is a 'relatively new form of governing' that grew out of a longer tradition of governing state populations by numbers: the census, the birth and death certificate, the examination (Ball 2015b; see also Ozga 2008; Selwyn 2014). As Stephen Ball argues, the modern school formed as an institution of 'differentiation, classification, and concomitantly of exclusion' in which people must be constantly measured against hegemonic expectations of normality and success (2015b, p. 299). One of the particularities of the neoliberal in this history of educational formation in Britain, however, is the late twentiethcentury replacement of 'rule-governed' education with 'goal-governed' education, which operates through the disciplinary monitoring of targets for outcomes and, in some cases, through more 'automated management' in which 'sources of data and analytics software [are used] to anticipate individuals' future lives' based on their existing performances (Williamson 2014, p. 99; see also Sedlar and Lingard 2014). Data (including 'big' digital data) and the digital technologies designed to produce, monitor and analyse it, 'have become interwoven with the new governance of educational institutions' and the production of 'governing knowledge' such that the futures of individual subjects are now dissembled, anticipated, and in cases altered algorithmically (Williamson 2014, p. 84; see also Mackenzie 2013; Selwyn and Facer 2013). In the educational context, this encourages the use of 'predictive' curricula, pedagogies and institutional policies that not only anticipate people's 'weaknesses', 'progress' or 'success' in school but, on the basis of such data, 'actively intervene to change their educational experiences and thus their future lives' (Williamson 2014, p. 100; Williamson 2015).

Yet this is no critical practice of anticipation; not a democratic or autonomous 'investment' in the active creation of undetermined futures, but the organization of the future as a site of anxiety and control. The use of predictive digital data as a tool of both policy-making and pedagogical practice is not only 'reinforcing and intensifying the culture of managerialism in education', but eliminating political, intellectual and discursive spaces for collective deliberation or normative judgements about what matters, and about the relationship between learning and the future itself (Selwyn 2015, p. 72; Fielding 2001). As the system cannot cope with open, complex and undetermined futures, there is 'a deliberate intention to reduce someone's range of options' through 'future-oriented preventative measures' (Lyon 2014, p. 5). The educational subject within this regime is split: on the one hand, dehumanized as a site and target of multi-governmental-level algorithmic decision-making; on the other, induced to actively (and enthusiastically) 'invest' learning energies in the satisfaction of targets and in the aversion of risks; to 'optimize' and 'enhance' oneself for performance in an algorithmically anticipated future - the worth of which can only be determined by the extent to which this performance produces 'human capital' and competitive market edge (Sedlar and Lingard 2014; Ozga 2009). The educational subject here is neither an active and unfinished learner nor a maker of worlds. Anticipatory consciousness is colonized by the statistical calculation of the future, as defined teleologically on the basis of present performances, and by the disciplining of accountability to this future in the present. 
In British compulsory education, this is accomplished most directly through the inspection of schools - and the spectre of inspection - by the Office for Standards in Education, Children's Services and Skills (OFSTED). While schools in Britain have been inspected by the state since the early nineteenth century (Case et al. 2000), the replacement of Her Majesty's Inspectorate of Education by the Office for Standards in Education (OFSTED) in 1992 instituted a new standardized monitoring, data-driven and eventually metricized framework of evaluation that would act as a steering mechanism to, in the words of chief schools inspector Chris Woodhead in 1999, 'help define the school's agenda for the future' (Case et al. 2000, p. 618; Ozga 2009). As Michael Fielding has argued,

'both OFSTED and "school effectiveness" are ontologically and axiologically bereft: neither has a considered view of what it is to be or become a person outside a de facto presumption of atomistic individualism; neither has a set of values that would enable it to make judgments about, for example, what might constitute "effectiveness" in other than market terms, and neither has a grasp of the proper relationship of means to ends' (2001, p. 702).

An example may serve to illustrate this point. First, in many schools in England, the weeks and months preceding a government inspection by OFSTED are toxic with anxiety. The determination of the future is felt by teachers to be entirely in the power of omnipotent judges whose perspectives, politics and intentions need to be anticipated in order to be fulfilled. Like an insurance scam or financial market, this process of recognition operates through a powerful 'injunction' or moral imperative for educators to anticipate: stay informed, up to date, alert, vigilant and 'ready for...the predicted inevitable', and above all to pre-empt surprises, unfinished tasks, uncertainties and the really new (Adams et al. 2009, p. 254). In order to minimize the margin of error in this risky activity, head teachers and others may engage in a range of what they regard as preventative practices: prescribing 'interventions' for children whose learning or behaviour needs to be accelerated or altered; recommending medication for children whose 'problematic' learning or behaviour cannot easily be influenced, 'gaming' test scores and other 'key performance indicators' (KPIs) to boost a school's position in the league tables, concentrating resources into the presentation of pupils, educational materials and buildings in order to pre-empt questions being raised about their substance, and etc. The financial costs and benefits of a select range of 'best practices' can now be carefully weighed using reductivist tools that calculate through positivistic methods its anticipated effectiveness, general cost, and ease of use. In the second example, evaluating and anticipating children's 'levels of progress', another basis upon which the effectiveness of schools is evaluated, is a particularly good example of what Adams et al. call 'abduction', or 'means of determining courses of action in the face of ongoing contingency and ambiguity', always towards the better inference of paths towards a predetermined end (2009, p. 255). The premise is scientifically simple: a teacher tests a child's present level of ability, determines what and how much they should learn within a given period of time according to the given standards, and then 'optimizes' their activity in order to ensure this target is achieved. If they are exceeded, we can factor them into the 'value added' by the school. This added value is only partly metaphorical, as indicated by the increasing emphasis in schools and universities on 'employability' as the primary purpose of education - in a world in which precarious labour is one of the most powerful generators of hopelessness and anxiety about the future.

In other words, anticipatory educational politics channel energies into an anxious witch-hunt for latent risks while simultaneously eroding the democratic sensibilities, relations and institutions which enable collective action and forward dreaming. The absence of collective 
and democratic dialogue about the relationship between the means of learning and the ends of social futures is not coincidental. At the level of global institutions, standardized tests and metrics, which are presently the 'chief instrument of educational governance' in such systems around the world (Tröhler 2010, p. 6), are also significant tools for international trade, economic competition and profit accumulation. National subscription to the Programme for International Skills Assessment (PISA), for example, is a 'significant income stream' for the OECD, which is among other bodies a 'major player in global higher education policy formation' (Shahjahan 2013, p. 677) and the production and evaluation of a wide range of educational data and bibliometrics now sustains booming academic and technological edubusinesses (Ball 2015b, p. 300; Grek 2013; Sedlar and Lingard 2014; Williamson 2014, 2015).

This is not the only thing sustained by this anticipatory regime. Riyad Shahjahan argues that it also reproduces coloniality, an embodied logic of geopolitical power that 'enforces control, domination, and exploitation disguised in the language of salvation, progress.... and being good for everyone' (2013, p., 679, citing Mignolo 2000) and, in doing so, denies alternative knowledges and imaginaries. In the context of education, for example, 'international' projects to standardize meanings, forms, contents and purposes of education which can be compared and even traded as commodities across institutions and countries as part of the "knowledge economy' - such as the OECD's PISA (in schools) and the Assessment of Higher Education Learning Objectives, or the European Bologna Process - impose narrowly instrumentalist, capitalist, Eurocentric epistemologies and criteria of value on the entire world. They also delegitimize and erase their alternatives. Thus, although educational institutions remain a 'vital public resource for addressing the multiple crises threatening our species and environment' (Fielding and Moss 2012), the imposition of institutional logics which construct the future in this way makes it impossible to organize learning towards these ends in ways that 'reopen the future, enlarge the space of possibility and...restore cultural confidence' (Kompridis 2006, p. 256), by drawing on the alternative epistemologies and pedagogies which circulate in marginalized educational traditions. .

Thus, although data-driven decision-making is often normalized in professional educational discourse as an objective and irresistible school-based or national activity, it is important to situate it within a more complex 'global infrastructure for human capital assessment' which parameterizes the nature of governance, the terms of global economic inclusion, and the possibilities for democratic futures (Sedlar and Lingard 2014, p. 932; Grek 2009). Under this regime, educators are far from 'working towards an educative relationship between schools and their communities', as Stephen Ball suggested that they must be (2013, p. 26), or from shifting schools in Britain 'from exam factories to communities of discovery' (Coffield and Williamson 2011, p. 27). This epistemological and practical foreclosure of spaces to contest and imagine a range of possible futures with and for children, teachers, schools and systems of organized learning is one manifestation of the wider 'crisis of hope' discussed at the beginning of this paper, contributing to a diminished state of affairs in which 'the capacity to envision alternative possibilities' is itself abolished (Kompridis 2006, p. 248; see also Amsler 2010; Brown 2015).

\section{Educational challenges to anticipatory regimes}

In an essay on high-stakes testing in the context of 'markets, managerialism and teachers' work', Howard Stevenson and Philip Wood (2013) argue that educational futures in the UK (and elsewhere, including the US, Australia and Canada) have been largely determined by the 
interests of business for thirty years. In this paper, we establish that these interests are pursued through the technologies of a post-democratic 'anticipatory regime' which forecloses the imagination of and experimentation with social futures in schools. Indeed, in many ways the institutions of British compulsory education are so colonized by anticipatory regimes that it is difficult to even imagine reclaiming them as sites for democratic educational practice. Where, then, are people systematically learning in critically anticipatory ways - learning how the emergent properties of the socio-material world can be reconfigured to invent new relations that are 'humanly worthy in process', and to recognize and create opportunities for the emergence of these relation in new settings (Bloch 1995, p. xx)? Where are the educational practices that enable "young people and communities to contest the visions of the future that they are being presented with, and to work together through the spaces of traditional and emergent democratic practice to fight for viable futures for all'? (Facer 2011, p. 15)

One source of evidence that anticipatory regimes are not necessary for quality education is the working of national systems of formal education, such as Finland and Singapore, which are not (or are much less) governed by repressive forms of anticipation, which minimize high-stakes standardized testing, marketization, managerialism and accountability, and which place higher esteem on teachers' professional judgement and autonomy, pedagogical dialogue, and school-community relations (Stevenson and Wood 2012, p. 56). As these systems still function within a broad consensus about the nature and location of 'learning' as a future-forming activity, however, for the remainder of this paper we will concentrate on exploring another orientation to the future that might be mobilised to continuously resist anticipatory regimes: autonomous, anti-colonial projects and institutions of learning located outside state and market educational systems, which are grounded precisely in a critique of the anticipatory underpinnings of modern 'education' itself. These seek not only to 'imagine the totality as something that could be completely different', but to learn how to make it so from now (Adorno in Bloch 1988, italics ours). Our thinking is inspired by writings from and about Amawtay Wasi (House of Wisdom), in Ecuador; the Escole Nacional Florsetan Fernandes, in Brazil; the Red Crow Community College, in Canada; the Swaraj University of the Shikshantar People's Institute for Rethinking Education and Development, in India; and the University of the Earth (or Unitierra), in Mexico (see also the website of the Enlivened Learning project (http://enlivenedlearning.com).

In the theories and practices made public by these projects, we find neither a desire to colonize the future through its algorithmic induction nor a resignation to abandoning it to power or chance, but pedagogies, curricula and modes of governance which are designed to enlarge spaces of possibility to participate in autonomous and common forms of life. Here there is a refusal to play the game of the anticipatory regime - no individualised targetsetting, strategic planning or algorithmic risk assessments - and a commitment to 'delink' from such regimes of epistemic and social control in order to enlarge the space of emergence for liberatory alternatives.

While each of these un/learning projects is singular to its own social and historical context, educational researchers who traverse between them suggest that all are distinguished by how they engage with learning and the future in ways that are 'not tamed, reduced, abstracted or detached' but rather through methods that start 'from our whole being and within our network of relationships with others, humans, non-human beings and things', and how they articulate an 'existential, embodied and non-future-oriented understanding and experience of hope' (Mandell 2014).. This mode of critical anticipation is positioned geopolitically in the margins 
and exteriorities of a world system that is otherwise represented as the only possible horizon of global knowledge politics. Here, abstract concepts of time and 'universal' criteria of value co-exist with many others, including those which are invisible and unrealized (Grosfoguel 2012). This perspective discloses the historical and geopolitical specificity - and interrupts the normalisation - of the repressive anticipatory regimes which are active in British education today. As Raymundo Sánchez Barraza, General Co-ordinator of the Fray Bartolomé de Las Casas Comprehensive Indigenous Training Center (CIDECI Las Casas) in Mexico, explained:

'we positioned ourselves from the beginning on the margins of prophetic critique, visà-vis history, vis-à-vis the world, vis-à-vis the demands of the minorities, the despised, conquered peoples...'. It is a 'shoeless university just from below' (2005).

The starting point for this critical anticipation emerges from the experience of violence. It starts from the impossibility of rational 'anticipation', as experienced by those who have historically been denied possibilities for self-determination through the interweaving of epistemic technologies with colonial oppression (Grosfoguel 2013; Mignolo 2000). The ambition of learners here is not to optimize their capacities to fulfil a predetermined future, particularly that of colonizing 'progress' which has annihilated indigenous people, lands, languages, knowledges and ways of life. Rather, it demands a kind of radical critique that the Argentine decolonial semiotician Walter Mignolo calls 'epistemic disobedience'. This is not a skill that can be learned through demonstrating 'progress' in learning against nationally standardized learning targets and outcomes; it requires the unlearning of what is presently required for inclusion and success in this system. Epistemic disobedience is not a method for more of the recognition or competitive advantage that promises fleeting future securities in a marketized anticipatory regime, but a "definitive rejection of "being told" from the epistemic privileges of the zero point what "we" are, what our ranking is in relation to the ideal of humanitas and what we have to do to be recognized as such' (Mignolo 2009, p. 3).

The epistemologies and technologies of the neoliberal anticipatory regime described earlier in this paper are excellent examples of the violence of a 'naturalized grammar of colonial modernity' which promotes certainty and linear causality, universal reason, teleology and linear time, the coherence of the Cartesian subject, the historical progression of a single humanity which can be reduced to standardized measures of evaluation, and the salvation of ontological, economic and political security within a framework of domination (Andreotti 2015 , p. 22). The pressing question for educators working against the colonization of the future by dominating social systems, however, is not how to minimize future risks to the advancement of these logics, but 'whether the world is going to survive' despite them and how to resist and survive the destruction of worlds in the present. From this point of departure, Barraza remarked, 'we're going by another path, not by this world's path with its model of profits, marketing, exploitation, greed, control, contempt for the different'. It is a path of learning and organizing autonomy and democracy, and creating conditions for new possibilities even - or especially - when these remain unknown and as yet unhoped for. Cofounder of the associated University of the Earth, Gustavo Esteva, elaborates this antiinstrumental relationship between learning and the future through the words of the dissident novelist and former Czech president Vaclav Havel, not as

'joy when things are going well or willingness to invest in enterprises that are obviously headed for early success, but rather an ability to work for something to succeed' and to value this process 'regardless of how it turns out', because it is this 
process, less so than the outcome, which 'gives us strength to live and to continually try new things, even in conditions that seem as hopeless as ours do, here and now' (Havel, cited by Esteva, in Mandell 2014).

This form of relating to the future allows for us to not predict or know the world in advance, but rather to be 'shocked' by it in the present, so that educational opportunity means making sense and embracing radically new perspectives, ideas and challenges without 'falling back into habits' of interpretation or domesticating them with scientifically rationalities (Mandell 2014).

\section{Reflections for future thinking}

At this point, there is inevitably an objection: this relationship to the future is plausible in the context of autonomous indigenous learning communities working in some parts of the global South, where 'the presence of the state and of capital is weak or distant' and therefore does not 'fully or at all organize the life of peoples in these places' (Aparicio and Blaser 2008), and where learning is articulated as part of actually-existing 'hope movements' which are radically reorganizing social life and redirecting social and ecological futures (Dinerstein and Deneulin 2012). But what possibilities are there for reasserting critical modes of anticipation within advanced neoliberal societies in the global North which are, as previously suggested, characterized by a hegemony of political impossibility; the 'undoing' of democratic forms of political agency, subjects, institutions and states; and the 'political construction of hopelessness - and moreover in educational settings where the continuation of these processes is assured through the imposition of data-driven, bureaucratically-governed technologies of anticipation? Moreover, what are the ethical implications of the Global North looking to those peoples and communities whom they have historically exploited and colonised as resources of their own salvation today?

We take heart from two insights afforded by the theoretical and practical alternatives introduced in this paper, which map loosely onto Boaventura de Sousa Santos's claim that 'the enlargement of the world occurs not only because the field of credible experiences is widened, but also because the possibilities of social experimentation in the future are increased' $(2014$, p. 175). The first is that it matters to know that the landscape of 'global education' is more diverse than suggested by its dominant representations in Anglophone media and discourses, and that multiple modes of anticipation co-exist with the technogovernmental regimes of Westernized capitalist schooling. In this knowledge, there is permission to refuse the heavy injunctions to await and prepare ourselves for the 'predicted inevitable'. It is possible to 'visualize many worlds outside the lens of institutionalized power' (Jain 2005) and to submit for consideration and experimentation futures beyond those seeded in the logic of corporate consumer capital - including those which have long been articulated by Anglo-European theorists and pedagogues of critical, democratic and emergentist anticipation which are subordinated by anticipatory regimes. This knowledge of alternatives opens up the opportunity for teachers, learners, scholars and activists in the global North to take responsibility for evolving forms of critical anticipation that are distinctive to their conditions; which are not parasitic upon but may be inspired by relations of collegiality with social justice movements in the global South.

The second insight is that liberating the future from the enclosures of capitalism and from the epistemological grip of the anticipatory regime is not a matter of identifying existing possibilities that can be successfully predicted given what is already known, but an 
experimental process of generating and enlarging the space of possibility itself through practices of critical, disobedient anticipation. The projects discussed above demonstrate that it is possible to create holistic, life-generating and possibility-enabling educational projects which re-establish critical relationships with the future rather than prohibiting them, and which seek to create the future open, working with novelty as a constantly evolving possibility rather than a totalising blueprint and model. In particular, they demonstrate how engaging learning with past, present and future in ways that 'negate the possibility of anticipating the future' can ground more critical, creative and collaborative pedagogies, curricula, forms of governance, and communities (Friedrich 2014, p. 275, italics ours). They do not simply embrace theories of the non-linearity and provisionality of complex realities (which, as Louise Amoore deftly illustrates, 'occupy the same terrain' of anticipatory regimes, 2014, p. 155), but demand continuous reflection on who benefits and who is harmed by the grammars of risk and possibilistic technologies which generate hopelessness in the face of algorithmically determined futures. Such work does not necessarily require hope-inadvance, as it may be 'the primary way we bring ourselves to take the risk of breaking out of the constraints of present conditions'; a method not for abolishing the anxieties of anticipation, but for overcoming complacency in the face of complexity and struggle (Duggan and Muñoz 2009, p. 281).

In reflecting explicitly on the possibilities of such decolonizing and inventionalist education within the context of 'institutions that more than often require fast, predictable and easily measurable outcomes that provide a sense of immediate reward and satisfaction to "clientlearners", Vanessa Andreotti (2016, p. 88) suggests that

'between enunciation (e.g. of a neoliberal educational agenda) and interpretation in a specific context (e.g. teachers "on the ground") lies a space of negotiation and creative opportunity that is always pregnant with (risky) possibilities. This space is extremely useful for those who can re-work these discourses and interfere in the geopolitical economy of knowledge production by displacing or interrupting certain constructions of meaning and enabling others. In this kind of work, the possibility of transformation of meaning and abyssal likes (i.e. border thinking) takes precedence over the compulsive description of reality-as-truth (which characterizes a project of neutralityuniversality). The role of an educator, as seen from this perspective, is as a cultural broker, negotiating between discursive systems: disrupting old patterns and creating new possibilities (always already embedded, contaminated, constrained and enabled by the context).'

Such modes of anticipation, which embrace learning as part of a process of working with the 'undecided material' of the present where 'the Unbecome is located and seeks to articulate itself' (Bloch 1995, pp. 148, 199), offer generative foundations for creating alternatives to contemporary regimes of anticipation in education in Britain today. 


\section{References}

Adams, V., Murphy, M. and Clarke, A. (2009) 'Anticipation: technoscience, life, affect, temporality', Subjectivity, 28: 246-265.

Amoore, L. (2014) The Politics of Possibility: Risk and Security Beyond Probability, Durham: Duke University Press.

Amsler, S. (2010) 'Bringing hope "to crisis": crisis thinking, ethical action and social change' in Skrimshire, S. (ed.) Future Ethics: Climate Change and Political Action, Continuum.

Amsler, S. (2015) The Education of Radical Democracy, London: Routledge.

Andreotti, V. (2011) Actionable Postcolonial Theory in Education, NY: Palgrave.

Andreotti, V. (2014) 'Critical literacy: theories and practices in development education', Special Issue - 'Finding the "historically possible": contexts, limits and possibilities in development education', Policy and Practice: A Development Education Review, 19, http://www.developmenteducationreview.com/issue19-focus1?page=show.

Andreotti, V. (2015) 'Mapping interpretations of decolonizatoin in the context of higher education', Decolonization: Indigeneity, Education and Society, 4(1): 21-40.

Andreotti, V. (2016) '(Towards) decoloniality and diversality in global citizenship education' in V. Andreotti (ed.) The Political Economy of Global Citizenship Education, London: Routledge.

Aparicio, J. R. and Blaser, M. (2008) 'The "lettered city" and the insurrection of subjugated knowledges in Latin America', Anthropological Quarterly, 81(1): 59-94.

Apple, M. (2000) Official Knowledge: Democratic Education in a Conservative Age, NY: Routledge.

Atasay, E. (2014) 'Neoliberal schooling and subjectivity: learning to desire lack', Subjectivity, 7: 288-307.

$\mathrm{Au}, \mathrm{W}$. and Ferrare, J. (2015) Mapping Corporate Education Reform: Power and Policy Networks in the Neoliberal State, NY: Routledge.

Ball, S. J. (2012) 'Show me the money! Neoliberalism at work in education', Forum: 3-19 Comprehensive Education, 54(1).

Ball, S. J. (2013) 'Education, justice and democracy: the struggle over ignorance and opportunity', Policy Paper, London: Centre for Labour and Social Studies (CLASS).

Ball, S. J. (2015a) 'Subjectivity as a site of struggle: refusing neoliberalism?' British Journal of Sociology of Education, DOI: 10.1080/01425692.2015.1044072. 
Ball, S. J. (2015b) 'Education, governance and the tyranny of numbers', Journal of Education Policy, 30(3): 299-301.

Barraza, R. (2005) 'Interview with Raymundo Sánchez Barraza: A university without shoes an indigenous intercultural system of informal education, San Cristóbal de Las Casas, Chiapas, Mexico', In Motion Magazine, http://www.inmotionmagazine.com/global/rsb_int_eng.html.

Bloch, E. (1995) The Principle of Hope, Cambridge, MA: MIT Press.

Bloch, E. (1988) 'Something's missing: a discussion between Ernst Bloch and Theodor W. Adorno on the contradictions of utopian longing', The Utopian Function of Art and Literature, Cambridge, MA: MIT Press.

Bronner, S. E. (2013) Of Critical Theory and Its Theorists, London: Routledge.

Brown, W. (2015) Undoing the Demos: Neoliberalism's Stealth Revolution, NY: Zone Books.

Case, P., Case, S. and Catling, S. (2000) 'Please show you're working: a critical assessment of the impact of OFSTED inspection on primary teachers', British Journal of Sociology of Education, 21(4): 605-621.

Coffield, F. and Williamson, B. (2011) From Exam Factories to Communities of Discovery: The Democratic Route, London: Institute of Education.

Cvetkovitch, A. (2012) Depression: A Public Feeling, Durham: Duke University Press.

De Lissovoy, N. (2011) 'Pedagogy in common: democratic education in a global era', Educational Philosophy and Theory, 43(10): 1119-1134.

DeRoo, N. (2013) Futurity in Phenomenology: Promise and Method in Husserl, Levinas, and Derrida, Fordham University Press.

Derrida, J. (2012) Spectres of Marx: The State of the Debt, the Work of Mourning and the New International, NY: Routledge.

Dewey, J. (2016) Experience and Education, US: Kappa Delta Pi.

Dinerstein, A. C. (2014) The Politics of Autonomy in Latin America: The Art of Organising Hope, NY: Palgrave.

Dinerstein, A. and Deneulin, S. (2012) 'Hope movements: naming mobilization in a postdevelopment world', Development and Change, 43(2): 585-602.

Duggan, L. and Muñoz, J. (2009) 'Hope and hopelessness: a dialogue', Women \& Performance: A Journal of Feminist Theory, 19(2): 275-283.

Fielding, M. (2001) 'Ofsted, inspection and the betrayal of democracy', Journal of Philosophy of Education, 35(4): 695-709. 
Facer, K. (2011) Learning Futures: Education, Technology and Social Change, London: Routledge.

Facer, K. (2012) 'Personal, relational and beautiful: education, technologies and John Macmurray's philosophy', Oxford Review of Education, 38(6): 709-725.

Facer, K. (2016) 'Using the future in education: creating space for openness, optimism and novelty' in H. Lees and N. Noddings (eds) Palgrave International Handbook of Alternative Education, NY: Palgrave Macmillan.

Fielding, M. and Moss, P. (2012) 'Radical democratic education', a proposal presented at the American Sociological Association annual conference, Denver, Colorado.

Freire, P. (1970/2000) Pedagogy of the Oppressed, London: Continuum.

Friedrich, D. (2014) 'The unfinished cosmopolitan as the embodiment of the paradoxes and promises of democratic education' in M. Perevra and B. Franklin (eds) Systems of Reason and the Politics of Schooling: School Reform and the Sciences of Education in the Tradition of Thomas S. Popkewitz, London: Routledge.

Grek, S. (2009) 'Governing by numbers: the PISA "effect" in Europe', Journal of Education Policy, 24(1): 23-37.

Grek, S. (2013) 'Expert moves: international comparative testing and the rise of expertocracy', Journal of Education Policy, 28(5): 695-709.

Grimaldi, E. (2012) 'Neoliberalism and the marginalisation of social justice: the making of an education policy to combat social exclusion', International Journal of Inclusive Education, 16(11): 1131-1154.

Grosfoguel, R. (2012) 'Decolonizing western uni-versalisms: decolonial plur-versalism from Aimé Césaire to the Zapatistas', Transmodernity: Journal of the Peripheral Cultural Production of the Luso-Hispanic World, Spring.

Grosfoguel, R. (2013) 'The structure of knowledge in westernized universities: epistemic racism/sexism and the four genocides/epistemicides of the Long $16^{\text {th }}$ Century', Human Architecture: Journal of the Sociology of Self-Knowledge, 11(1): 73-90.

Henderson, J. and Hursh, D. (2014) 'Economics and education for human flourishing: Wendell Berry and the Oikonomic alternative to neoliberalism', Educational Studies: A Journal of the American Educational Studies Association', 50(2): 167-186.

Hursh, D., Henderson, J. and Greenwood, D. (2015) 'Environmental education in a neoliberal climate', Environmental Education Research, 21(3): 299-318.

Jain, M. (2005) 'Shikshantar: The Peoples' Institute for Rethinking Education and Development', Journal of Futures Studies, 10(1): 115-118.

Kompridis, N. (2006) Critique and Disclosure: Critical Theory between Past and Future, Cambridge: MIT Press. 
Lyon, D. (2014) 'Surveillance, Snowden and big data: capacities, consequences, critique', Big Data \& Society, http://dx.doi.org/10.1177/2053951714541861.

Mackenzie, A., and Vurdubakis, T. (2011) 'Codes and codings in crisis: signification, performativity and excess', Theory, Culture \& Society, 28(6): 3-23.

Mallana, K. and Greenwa, R. (2011) "Radiant with possibility": involving young people in creating a vision for the future of their community', Futures, 43: 374-386.

Mandell, U. (2014) 'Relearning hope', Enlivened Learning blog, 24 February, http://enlivenedlearning.com/2014/02/26/re-learning-hope/.

Masschelein, J. and Simons, M. (2011) 'Experimentum scholae: the world once more ... but not (yet) finished!' Studies in Philosophy of Education, 30: 529-535.

Mignolo, W. (2000) Local Histories/Global Designs: Coloniality, Subaltern Knowledges and Border Thinking, NJ: Princeton University Press.

Mignolo, W. (2009) 'Epistemic disobedience, independent thought and decolonial freedom', Theory, Culture \& Society, 26(7-8): 1-23.

Osberg, D. (2010) 'Taking care of the Future? The complex responsibility of education and politics' in D. Osberg and G. Biesta (eds) Complexity Theory and the Politics of Education, Sense Publishers.

Ozga, J. (2009) 'Governing education through data in England: from regulation to selfevaluation', Journal of Education Policy, 24(2): 149-162.

Paraskeva, J. (2016) Curriculum Epistemicide: Towards an Itinerant Curriculum Theory, NYL Routledge.

Robertson, S. (2007) "'Remaking the word": neo-liberalism and the transformation of education and teachers' labour' in L. Weis and M. Compton (eds) The Global Assault on Teachers, Teaching and their Unions, NY: Palgrave.

Ross, W. and Gibson, R. (2007) Neoliberalism and Education Reform, Hampton Press.

Santos, B. (2014) Epistemologies of the South: Justice against Epistemicide, NY: Routledge.

Sedlar, S. and Lingard, B. (2014) 'The OECD and the expansion of PISA: new global modes of governance in education', British Educational Research Journal. 40(6): 917-936.

Selwyn, N. (2015) 'Data entry: towards the critical study of digital data and education', Learning, Media and Technology, 40(1): 64-82.

Selwyn, N. and Facer, K. (eds) (2013) The Politics of Education and Technology: Conflicts, Controversies and Connections, NY: Palgrave.

Shahjahan, R. (2013) 'Coloniality and a global testing regime in higher education: unpacking the OECD's AHELO initiative', Journal of Education Policy, 28(5): 676-694. 
Simon, B. (1985) Does Education Matter? London: Lawrence and Wisehart.

Stevenson, H. and Wood, P. (2013) 'Markets, managerialism and teachers' work: the invisible hand of high stakes testing in England', The International Education Journal: Comparative Perspectives, 12(2): 42-61.

Stevenson, N. (2015) 'Revolution from above in English schools: neoliberalism, the democratic commons and education', Cultural Sociology, 9(4): 534-549.

Torres, C. A. (2008) Neoliberalism and Educational Globalization, NY: Routledge.

Tröhler, D. (2010) 'Harmonizing the educational globe: world polity, cultural features, and the challenges to educational research', Studies in Philosophy and Education, 29: 5-17.

Van Heertum, R. (2006) 'Marcuse, Bloch, Freire: reinventing a pedagogy of hope', Policy Futures in Education, 4(1): 45-51.

Williamson, B. (2016) 'Digital education governance: data visualization, predictive analytics, and "real-time" policy instruments', Journal of Education Policy, 31(2): 123-141.

Williamson, B. (2015) 'Governing software: networks, databases and algorithmic power in the digital governance of public education', Learning, Media and Technology, 40(1): 83-105.

Wilkins, A. (ed) (2012) 'Neoliberalism, Pedagogy and the Curriculum: A Global Perspective', themed issue of the Journal of Critical Pedagogy, 3(2), https://www.degruyter.com/view/j/jped.2012.3.issue-2/issue-files/jped.2012.3.issue-2.xml. 